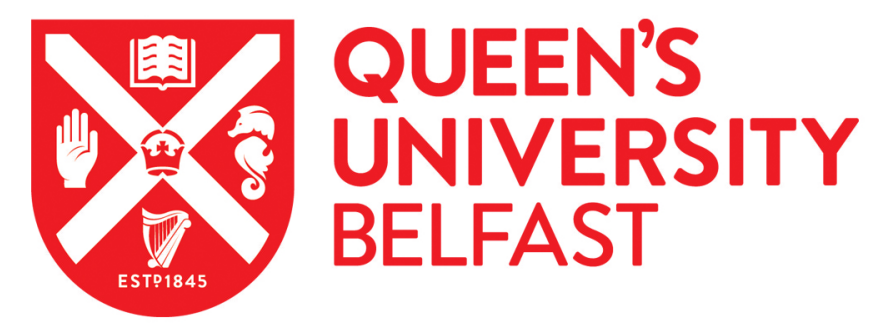

\title{
From Comparative Analysis to Final Publication: Nationalism and Globalization in English and Italian Football Since 1930
}

Penn, R. (2018). From Comparative Analysis to Final Publication: Nationalism and Globalization in English and Italian Football Since 1930. SAGE Research Methods: Cases, Part 2. https://doi.org/10.4135/9781526445308

\author{
Published in: \\ SAGE Research Methods: Cases
}

Document Version:

Publisher's PDF, also known as Version of record

Queen's University Belfast - Research Portal:

Link to publication record in Queen's University Belfast Research Portal

Publisher rights

(C) 2018 Sage Publications.

This work is made available online in accordance with the publisher's policies. Please refer to any applicable terms of use of the publisher.

\section{General rights}

Copyright for the publications made accessible via the Queen's University Belfast Research Portal is retained by the author(s) and / or other copyright owners and it is a condition of accessing these publications that users recognise and abide by the legal requirements associated with these rights.

Take down policy

The Research Portal is Queen's institutional repository that provides access to Queen's research output. Every effort has been made to ensure that content in the Research Portal does not infringe any person's rights, or applicable UK laws. If you discover content in the Research Portal that you believe breaches copyright or violates any law, please contact openaccess@qub.ac.uk. 


\section{@SAGE researchmethods \\ cases}

\section{From Comparative Analysis to Final Publication: Nationalism and Globalization in English and Italian Football Since 1930}

Contributors: Roger Penn

Pub. Date: 2018

Access Date: March 21, 2018

Academic Level: Postgraduate

Publishing Company: SAGE Publications Ltd

City: London

Online ISBN: 9781526445308

DOI: http://dx.doi.org/10.4135/9781526445308

(C)2018 SAGE Publications Ltd. All Rights Reserved.

This PDF has been generated from SAGE Research Methods Cases. 


\begin{abstract}
This case study explores the processes of research involved in the cross-national comparative case study of English and Italian football since 1930. It examines these through a succession of stages. The initial development of the research topic is outlined and the operationalization of the empirical research questions is explained in detail. The analysis of the data using Microsoft Excel is detailed and illustrated and the theoretical orientations that underpinned both the choice of research questions and their interpretation in the final published article are explored. The issues of nationalism, globalization, and nationality are also covered. The importance of some level of competence in the Italian language is also probed, as language competence is an important issue in much cross-national research. The case study discusses the interplay of data analysis and sociological explanation and provides a clear analysis of how the research became a published article in a refereed academic journal. The case study provides a set of exercises and research questions as well as further readings to facilitate a wider understanding of the issues involved in cross-national comparative case studies.
\end{abstract}

\title{
Learning Outcomes
}

By the end of this case, students should be able to

- Understand how to operationalize research questions

- Grasp how to present quantitative data within a wider interpretative context

- Comprehend how to link the collection of data with wider sociological conceptual frameworks

- Understand the various stages that a research project must go through from its first beginnings to its final publication in an academic journal

\section{Introduction}

The central purpose of this case study is to provide an explanation of how my article "Football, Nationalism and Globalization: A Comparison of English and Italian Football Between 1930 and 2010" (Penn, 2013), published in the European Journal for Sport and Society, was created. It also aims to outline the comparative case studies of football in England and Italy upon which it was based and the wider sociological set of concepts and theoretical approaches integral to the analyses and interpretation provided.

The research derived from my increasing general interest in the sociology of football over the preceding 10 years. This had produced a series of published articles in various British and Italian sociological outlets. These included research on stadia and also upon the behavior of 
spectators in both England and Italy (see Penn, 2004, 2005, 2006a) as well as the incorporation of wider tropes from economic sociology - my traditional area of expertise-into the analysis of the economic and cultural aspects of football (see Penn, 2000, 2002, 2008).

These developing interests led my then Head of Department at Lancaster University to encourage me to teach a new course on Football \& Society in 2008 . In creating this course, I wanted to examine football sociologically using new theoretical and empirical approaches and to avoid the excessive (in my mind) emphasis traditionally within the field on spectator violence and football "hooliganism." I achieved this by examining football and health (Penn, 2009) and also the burgeoning relationship of football with the military (Penn \& Berridge, 2016). Another area that I focused upon from the start was the debate about globalization and football.

\section{The Development of the Research Topic}

The central aim of the research was to explore the globalization of professional football in the current era by examining the changing national origins of players, managers and owners in English and Italian football. The precise research topic developed through a series of iterations. This is standard practice in social science both in its qualitative (Bickman \& Rog, 2009) and quantitative forms (Black, 1999). Initially, I examined the national origins of players, coaches (managers), and owners in the English Premier League in 2010 in an attempt to explore the degree to which all three had increasingly global origins. However, it soon became apparent that these contemporary patterns needed to be contextualized through an historical comparison to establish how new they were. This led subsequently to a comparison of the same phenomena in the English First Division in 1970. (Between 1930 and 1992, the top tier of English football was called the First Division. Since 1992 it has been rebranded as the Premier League.)

The next stage entailed an extension of the data on English top tier football to include a comparison with Italy to see if the patterns uncovered were universal. Serie A's players in Italy in 2010 were compared with those playing in the English Premier League at that time. However, a similar comparison for 1970 hit an immediate obstacle: foreign players were banned from Italian football between 1965 and 1980. Therefore, I changed the focus slightly to probe players, coaches, and owners in Serie A in 1989. This was almost a decade after the ban on foreign players in Italy had been rescinded and seemed an appropriate point in time to make a comparison. As a result of these initial analyses, I extended the research longitudinally to incorporate a much longer time frame. I collated information from England and Italy for the 1930s and 1950s, thereby creating the full data set upon which the published article was based. 
Why did the research commence in 1930 ? The answer was straightforward. Serie A in Italy was inaugurated as a full-time professional league on a par with the English First Division in the $1929 / 1930$ season, and therefore, it would have been impossible to go further back in Italy. However, there still remains the possibility to extend the analysis of English football further back to at least 1888 (see Penn \& Berridge, 2016).

\section{The Operationalization of the Research Questions}

The aim of the research was to track the trajectories of the national origins of football players, coaches and owners in England and Italy since 1930. For the 2010/2011 season in England data were collected on English Premier League squads as reported to the Football Association (FA) in England and reproduced on the BBC Sport website on September 24, 2010. The BBC website is a recognized authoritative source for reliable data on football due to the high standards of professionalism imposed by the BBC on its journalists. The information was corroborated through data published subsequently in the European Football Yearbook for $2011 / 2012$ (Hammond, 2011). The data reported by the BBC proved to be $100 \%$ reliable.

Data on the 1970/1971 season in England were collated from the Rothmans Football Yearbook 1971-72 (Camkin, 1971). The Rothman's Football Yearbook has been published annually since 1970 and is recognized by social scientists and journalists as the authoritative source for information on players, coaches and owners. However, in 1970, First Division clubs did not have "squads" in the contemporary sense. They had larger pools of professional players registered to their clubs. To ensure approximate equivalence their "squads" were defined as including all players who played 5 or more league games for their clubs during that season. I collated and entered the information into Microsoft Excel. The data for the 1930s and 1950s in England were garnered from the two FA Cup final teams during those decades. It proved impossible to locate systematic data on league squads but each Cup Final had a separate entry in Wikipedia which listed the 22 players and two managers from the two Finalists. Wikipedia is a potentially controversial source for information. Some academics reject its use but extensive additional research into other secondary sources revealed that the data in Wikipedia were authoritative and reliable. One reason for this lies in the nature of Wikipedia itself which allows errors to be challenged by readers. Given the centrality of football to English culture (see Penn, 2016) any putative errors are highly likely to be challenged and rectified. My own corroborative research revealed no errors. However, as with all sources of data, it is important to verify its reliability through a process of cross-checking and triangulation with other secondary data sources.

This generated a total of 220 players per decade, and their respective places of birth and nationalities were established via extensive biographical research on the Internet. Each player 
had an individual biographical entry in Google. The same procedure was followed in relation to the 22 managers. Extensive research into the owners of top tier clubs in 1970 and 2010 and of FA Cup Finalists in the 1930s and 1950s was conducted mainly via Wikipedia entries which detailed their places of birth and nationality. I also collated and subsequently entered these data into Excel.

The Italian data for the 2010/2011 season were taken from the September 2010 issue of Calcio Italia (this is a popular monthly magazine devoted to Italian football published in English) and corroborated via the European Football Yearbook for 2011/2012 (Hammond, 2011). This is an annual publication from the Union of European Football Associations (UEFA) that is very reliable. The evidence for the $1988 / 1989$ season was derived from the Annuario del Calcio Mondiale, 1988/1989 (Presti, 1988). This is an annual publication in Italy and parallels the Rothman's Yearbook in England. Data for the 1930s and 1950s were based on details of the winning teams of the Serie A title in these decades garnered from the Dizinario del Calcio Italiano (Sappino, 2000), a major historical source for information on the history of Italian football. I examined this information against the players' and coaches' Wikipedia entries (these were generally in Italian) and some were also cross-checked with Italian sociologists who were experts in football. My colleague, Professor Alex Baroncelli of Cattolica University in Milan proved of particular assistance with this. The same procedure was employed to collect information on the nationality of owners of Serie A clubs.

I initially transcribed the data by hand and then inputted them into Excel prior to analysis. Figure 1 provides a screenshot of an Excel spreadsheet that was used to generate subsequent graphs and tables. 
Figure 1. Excel spreadsheet of data.

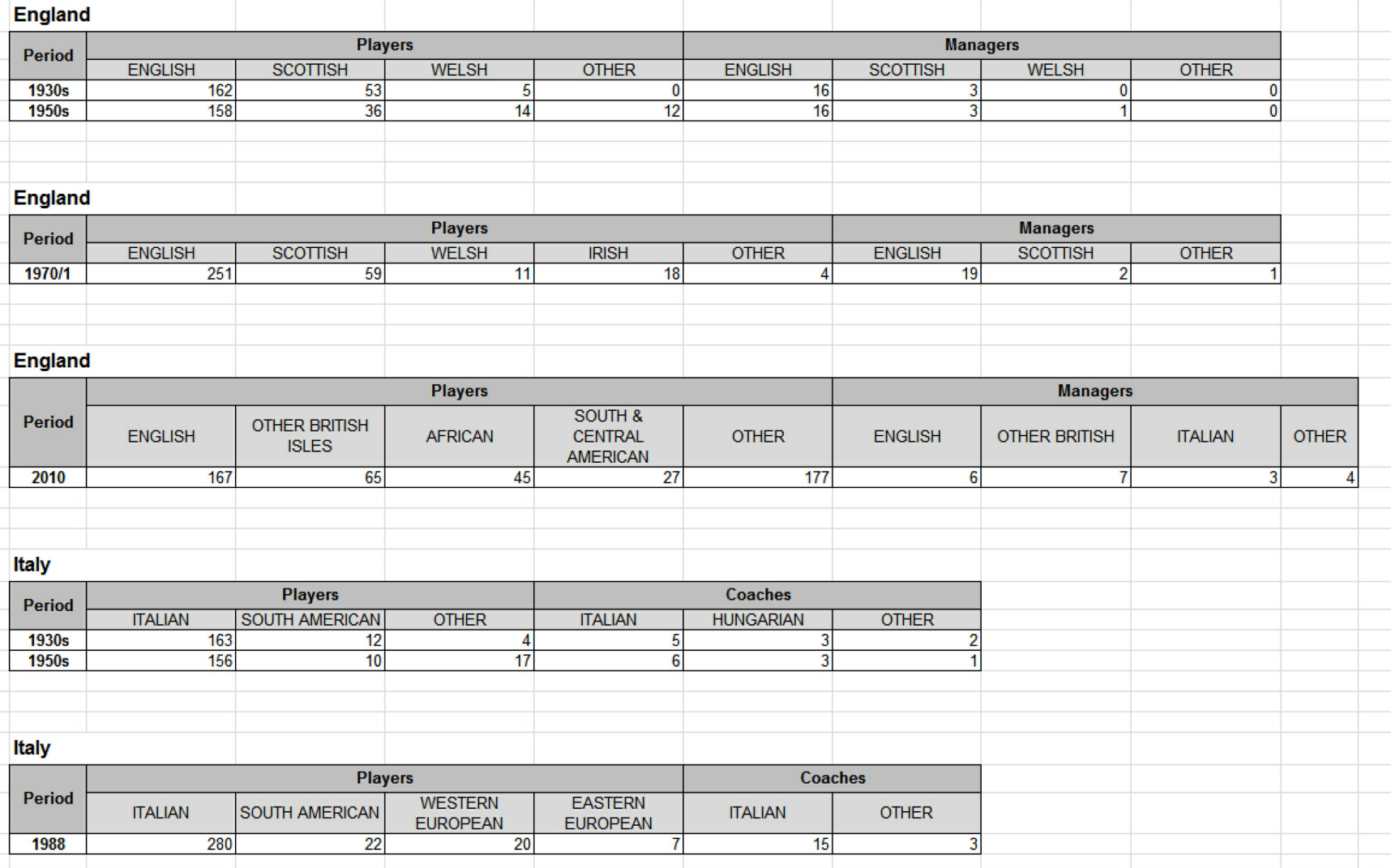

I also retained hard copies of my categorizations and data collection in a folder which proved invaluable when writing the current article. As a matter of good practice, it is vital to retain copies of any data collected and transformations made through subsequent re-coding.

\section{The Analysis of the Data: Theoretical Orientations}

The analysis of the data was underpinned by three theoretical orientations. However, these did not in themselves prompt the research; rather, they molded my argument as it developed during the interpretation of the results. These three approaches derived from economic sociology in the main rather than the conventional tropes within the sociology of sport. The first involved exploring social change through the examination of long-term structural change. This form of analysis is associated with the French Annales school which pioneered the combination of historical, demographic and sociological methods of research (see Braudel, 1979; Burke, 1972; Le Roy Ladurie, 1978) and has been used recently by several authors to explore football and social change (James, 2016; Penn, 2013).

The second involved the use of contingency theory which is anchored in organizational sociology (see Morgan, 2007). This is based upon the insight that there is no best way to organize a corporation that can be deduced from theoretical first principles. Rather, there are a 
set of empirical possibilities dependent upon a wide range of contextual factors. These ideas have gained greater currency within the wider field of economic sociology in recent years and emphasize the need for generalizations to be derived from inductive reasoning based on empirical case studies as well as upon conventional theoretical abstractions (see Whitley, 2000, 2007). This method was integral to the comparative research design I used.

The third element involves the use of comparative national case studies (see Harkness, van de Vijver, \& Mohler, 2003; Hoffmeyer-Zlotnik \& Wolf, 2003) to explicate sociological variations empirically. This approach is rooted in survey methodology and emphasizes the need for systematic quantitative data for effective comparative analysis (see Etzioni \& Dubow, 1970). It is based on notions of "control" in the absence of classic experimental data. Comparative research matches empirical case studies to probe the nature of sociological generalizations and specificities. Such a heuristic orientation has been developed extensively in the field of economic sociology (see Penn, 1990, 2006b; Penn \& Lambert, 2009) but less so in the sociology of sport.

These three approaches share certain key theoretical methodological assumptions. The first is that there are important empirical variations in the nature of contemporary social phenomena which are both historical and geographic in nature. These variations cannot be reduced to the imposition of a pre-conceived set of abstract a priori principles. Second, these three approaches support the analysis of systematic empirical data and not the selection of a few concrete examples that (inevitably) fit. My research incorporated all three sets of theoretical principles. My research involved a long-term structural comparison of two national case studies, and it used systematic empirical data to compare the national origins of players, coaches, and owners

The Interpretation of the Data

\section{Globalization and Nationalism}

The two key concepts that underpinned the interpretation of the patterns of national origins of players, coaches, and owners in England and Italy were nationalism and globalization. Both are central to contemporary social scientific analyses of modern societies and both share certain hermeneutic elements. Nationalism and globalization constitute metanarratives of how the world has changed and is still changing. The growth of nationalism and the emergence of nation-states has a long history. England has been an independent country for at least 950 years. France, Spain, and Denmark likewise have also existed in national form for centuries but most social scientists argue that the emergence of modern nationalism can be dated from 
the time of the French Revolution. Certainly, the emergence of nation-states has developed continuously since then.

Globalization has often been seen as the antithesis of nationalism and as a homogenizing process whereby all national differences are progressively eradicated. Many cultural commentators and politicians lament the loss of "difference" and concomitant local authenticity that they see as integral to this. To link the trajectories of national origins of players, coaches, and owners in England and Italy, my research explored nationalism and globalization as it applied to football. Much of this involved an examination of previous historical and sociological research on the topic. In many respects, this part of the research process represented an extensive literature review which is a cornerstone of all social scientific research. This secondary literature ranged widely and included materials on international migration, political and legal systems, and changing national borders.

\section{Nationalism}

From its inception football has been powerfully affected by nationalism and national templates. Football clubs are primarily regulated by national federations and compete in national leagues. Traditionally, football players, managers (coaches), owners, and spectators all came from the same nation. National forms of social organization were the axial principle for football historically and remain powerful today.

Football became international when these national federations formed international governing bodies such as the International Olympic Committee in 1894 and the Fédération Internationale de Football Association (FIFA) in 1904. These organizations quickly developed international football competitions. Initially, this involved Olympic competitions for men from 1908 and subsequently Football World Cups for men after 1930. Nevertheless, these competitions took place within overarching national templates: teams participated on the basis of nationality and still do. As new nations have emerged over time, they have also sought affiliation to these international bodies and to participate in international competition. The newest nation, South Sudan, played a football international against Uganda within months of its independence in 2011. This emergence of international football at the end of the 19th century and in the early 20th century paralleled the wider growth of international political organizations such as the International Committee of the Red Cross, the League of Nations and the International Labour Office.

Football remains both national in its organizing principles and international in that national organization inevitably entails international forms of competition and regulation. The competitive logic of the national templates that underpin international contests within football can be seen 
in their purest form when two national teams line up before international matches and the respective national anthems are sung and their flags flown.

\section{Globalization}

In recent years, there has been considerable debate among social scientists about the globalization of football, a great deal of which is speculative and overly abstract (see Giulianotti, 1999; Giulianotti \& Robertson, 2009). These approaches are teleological in orientation; globalization is generally portrayed as a unilinear, eschatological, and unidirectional process. Systematic empirical data to support these conjectural approaches are, however, generally absent from these accounts. Rather, a succession of examples is selected to fit such explanations. The research undertaken into Italian and English football was designed to generate systematic quantitative data and to provide a rigorous examination of the trajectories of national origins since 1930.

For heuristic purposes, it was necessary to distinguish two main phases to globalization in football. Football became a global game very swiftly from the mid-19th century onwards. The FA was created in 1863 in London and codified the laws of the game in that year. Football spread rapidly to the rest of the United Kingdom. It also spread further afield as a result of British commercial imperialism in the final third of the 19th century. Football clubs were created by merchants, textile manufacturers and those involved in the construction of the South American railway system. However, this dispersion of football took place within a system of nation-states which formed the context for subsequent international competitions such as the South American Championship (now the Copa América) and the Mitropa Cup (a precursor to the Champions League played between club teams in Central Europe between 1927 and 1992). Indeed, international competition in football was an essential component of the nationalistic template dominant in the late 19th century. It continues to resonate powerfully in the contemporary era.

More recently a new form of globalization has emerged, and football can been seen as an exemplar of these changes (see Giulianotti \& Robertson, 2004, 2009; Maguire, 1999). This newest phase of global football incorporates a series of inter-related elements. Central to this has been the emergence of global television coverage of club and international competitions. This has promoted and enhanced the development of global footballing brands such as Manchester United, Real Madrid, Barcelona, and Juventus. These clubs are supported by global fan bases. There is also global sponsorship of club competitions and World Cups involving companies like Coca-Cola, McDonalds, Visa and Sony. Nevertheless, national templates remain very powerful. As yet there is little evidence of the emergence of supra- 
national leagues and concomitant global competition. This is in contrast with Rugby Union in the southern hemisphere where clubs from Australia, New Zealand, South Africa, Argentina and Japan currently compete in the Super Rugby club competition. Indeed, club competitions within football remain predominantly national in scope. International club competitions like the UEFA Champions League and the Copa América are predicated upon prior success in national leagues.

However, a notable feature of the development of this latest phase of the globalization of football has involved the increasingly diverse national origins of football players in the five major European leagues in England, France, Germany, Italy and Spain. This has been paralleled by the increasing diversity of coaches (managers), owners and, to a lesser degree, of spectators themselves.

The empirical cornerstone of my research involved an examination of the contours of these changes within English and Italian football since 1930. English and Italian football have been major forces in European football over the last century. The English league was created in 1888 and Italy's Serie A in 1929. The research involved a matched longitudinal comparison of the two countries since 1930 and was designed to provide rigorous and systematic comparative data on the national origins of players, managers/coaches and owners over this period.

\section{Nationality}

A central concept in my research involved the notion of nationality. This proved a tricky concept to operationalize in practice and led the research into a range of new areas relating to national identity, international migration and the rules used by nation-states to determine access to their labor markets. Football is an industry and as such is closely affected by these national regulations. As became clear during this part of the research process, these regulations varied historically and their characteristics strongly affected the flows of football players and coaches from outside countries like England and Italy. Perhaps the most graphic example of how fluid nationality can be in certain contexts involved the case of Luis Monti who was Argentina's star player during the 1930 World Cup tournament in Uruguay but went on to represent Italy in its World Cup victory over Czechoslovakia in 1934.

Similar complexities surrounded the categorization of players and coaches in English football. English is not a nationality "per se." It can be a national identity but all citizens of the United Kingdom are British. However, owing to the historical peculiarities of the historical emergence of codified football in Britain, there are four "Home Nations" (England, Scotland, Wales and Northern Ireland). In addition, in the late 19th century what is now the Republic of Ireland was part of the United Kingdom. The coding of nationality for the purposes of my published 
research was operationalized initially as place of birth. I then triangulated this against the country that the player represented internationally. This produced a fivefold categorization: English, Scottish, Welsh, Northern Irish, and Southern Irish.

However, the legacy of Irish independence in 1922 meant that citizens of Eire (subsequently the Republic of Ireland) enjoyed the same political rights as the U.K. population. There have been no restrictions on Irish footballers' from the Republic of Ireland access to English football. The same also applied traditionally to citizens from British Dominions and colonies such as South Africa, Australia, and the West Indies. The provisions of the British Nationality Act in 1914 and the 1919 Aliens Act severely restricted access of other "foreign" players to English football. These rules were enforced until 1973 when Britain joined the European Common Market which transformed the British labor market. Henceforward, players from the Common Market (subsequently the European Union) had free and unrestricted access to the U.K. labor market. This applied to football.

The situation in Italy was, if anything, more complex and required detailed further historical research. The early origins of football in Italy were determined largely by the influence of British migrants. Several Italian clubs still retain their original English names-A. C. Milan and Genoa, for example. This is testament to their founders who came from Britain in the late 19th century. By the early 1920s, there were a significant number of British, Austrian, and Hungarian nationals playing in Italy. This changed abruptly when Benito Mussolini's Fascist government took control of Italian football in the mid-1920s and adopted a series of ultra-nationalist, autarkic policies. In 1926, all foreigners were banned from playing in Italy as a result of the Carta di Viareggio (Charter of Viareggio). This was passed after the accession to power of Mussolini and his Fascist Party in Italy in 1923. A cornerstone of Fascist ideology was the desire for national self-sufficiency (autarky) both economically and within wider social and cultural spheres.

However, exceptions were made for players of Italian origins born and living in the global Italian diaspora. This applied particularly to those from Argentina, Uruguay, and Brazil, all of which had received millions of Italian emigrants. Their children were categorized as Italian under the Carta di Viareggio and as players labeled as rimpatriati (repatriated). Vittorio Pozzo, the Italian manager of the 1934 and 1938 World Cup-winning Italian teams, responded to international criticisms of his use of rimpatriati with the orthodox contemporary view that "according to Italian law, the sons of Italians born abroad are considered Italians" (Pozzo, 1960).

There was a very similar set of factors at work during the 1950s. Many players from South America had Italian ancestry and were now classified as oriundi (immigrants with family roots in Italy). Some indeed became full Italian internationals, after moving from South America to Italy 
most notably the Argentines, Humberto Maschio and Omar Sivori; the Brazilians, Angelo Sormani and Jose Altafini; and the Uruguayans, Alcides Ghiggia and Juan Schiaffino. However, the poor performances by Italy in a succession of World Cups between 1950 and 1962 led to the complete ban on foreign players in Italy between 1965 and 1980. Despite the successful Italian campaign in Mexico in 1970 when the Italian national team (the Azzurri) lost in the World Cup final to Brazil, the national team reverted to mediocrity during the 1974 and 1978 World Cup competitions and eventually the ban on foreign players in Serie A was rescinded in 1980.

A further complication centered upon the area known as Istria and Fiume. This area had been part of the Austro-Hungarian Empire until 1918. After 1921, it became part of Italy until 1945. Henceforward, Fiume lay in Croatia and Istria was divided between Slovenia and Croatia. This meant that a player born in these areas in 1916 would have been born in Austria-Hungary, but by the 1930s, his birthplace would have been located in Italy and after 1945 it would have lain either in Croatia or Slovenia. Such players would also have been Italian speakers and in all likelihood would have considered themselves Italian.

\section{Italian Language}

A central question for any reader of this case study involves the issue of the Italian language and how this affected the research methods used. Many of the key sources were written in Italian (see Presti, 1988; Sappino, 2000) but most of the material extracted in Italian were fairly straightforward (names of players and their place of birth and nationality) or could be translated into English easily. Probably of more importance for the research was my earlier collaboration with Italian sociologists on the sociology of football. Professors Alex Baroncelli in Milan (originally in Bologna) and Professor Everardo Minardi at the University of Teramo were particularly helpful. I gained an understanding of Italian football culture through them and their encouragement supported the research discussed in this case study. In the end most of the research using Italian language sources was conducted using a dictionary. More recent data on Italian football is available in English from the annual European Football Yearbook.

\section{The Connection Between the Data and the Explanation}

The empirical evidence on the national origins of players, coaches and owners in England and Italy involved a complicated data collection process. It also involved operational decisions on how to categorize such national origins. Nonetheless, the interpretation of the patterns uncovered were not determined by quantitative analysis. The descriptive statistics used in the research were mainly graphical in form, plus some tables (see Figure 2 and Table 1). Both graphs and tables were generated in Excel. 
Figure 2. Trajectories of national origins.

GRAPH: TRAJECTORIES OF NATIONAL ORIGINS IN ENGLISH \& ITALIAN FOOTBALL 1930-2010

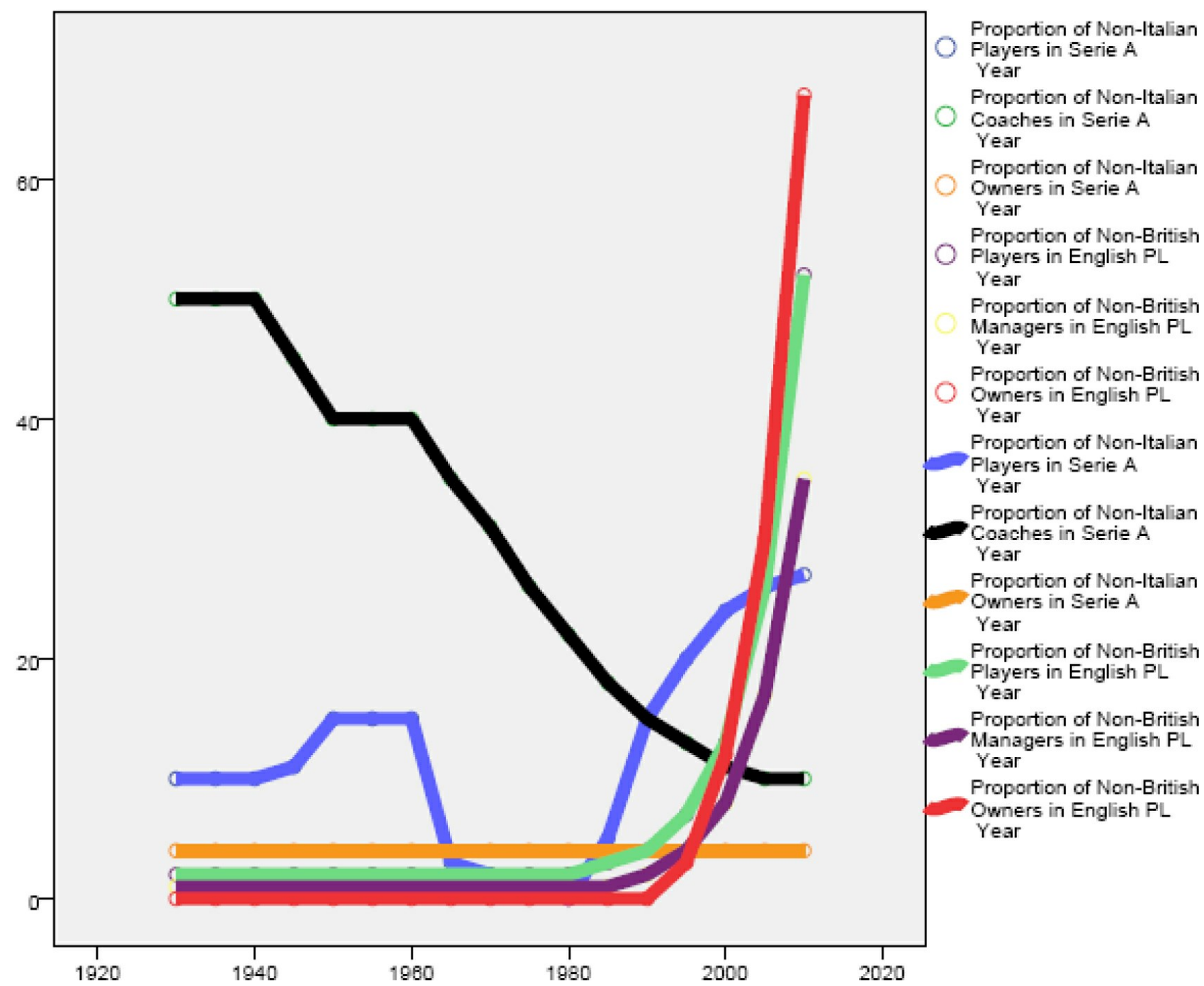

Table 1. National Origins of Players in Italian Top Tier Football [Percentages].

\begin{tabular}{|l|l|l|l|l|}
\hline & $1930 s$ & $1950 s$ & 1988 & $2010 / 2011$ \\
\hline Italian & 91.1 & 85.2 & 85.1 & 56.6 \\
\hline South American & 6.7 & 5.5 & 6.6 & 19.2 \\
\hline African & - & - & - & 3.6 \\
\hline Other & 2.2 & 9.3 & 8.2 & 20.7 \\
\hline
\end{tabular}


Numbers never speak for themselves. The explanation had to be consistent with the empirical data but was also based upon extensive historical and contemporary research into a range of fields. These included the sociology of football in England and Italy but also the sociology of international migration and the regulation of national labor markets. This part of the research was much more time-consuming than the data collection and analysis. The overall interpretation was closely linked to the three conceptual/theoretical approaches outlined earlier. The explanation incorporated the notions of deep structures and conjunctural change. The patterns uncovered were based upon a comparison of two national case studies and were contingent in nature: they depended on flows of players, coaches and owners that had been affected by specific circumstances. They were not determined outside human agency and can be reversed. Indeed, they may well change in the future. The interpretation of the empirical evidence involved a creative interplay between the conceptual frameworks that underpinned the overall hermeneutic process and the data analysis itself.

\section{The Process of Publication}

The process whereby an embryonic analysis becomes a published article in a scholarly refereed journal can be tortuous and intimidating. Once I completed the analysis, I presented the results at three venues. The first was at the University of Central Lancashire in 2011 (a video of the presentation alongside the Power Point slides is available on the Internet at https://vlas.uclan.ac.uk/Play/5305). After revisions, I presented a new version to a Departmental Seminar at Queen's University in Belfast in 2012 and a subsequent version at the European Association for the Sociology of Sport Annual Conference in Cordoba in 2013. The comments received at Cordoba led me to submit a re-revised manuscript to the journal European Studies for Sport and Society. The reviewing process, which involved two anonymous reviewers' reports and helpful comments from the editor (Professor Siegfried Nagel), required me to make further modifications to the text. The paper was accepted for publication in 2013. However, the publication process brought unexpected problems. The publisher of the journal at the time could not reproduce the graphical representations of the data in color (see Figure 3). This was not stated on their website. Even more frustratingly they also did not like most of the black and white versions of the pie charts and graphs either (see Figure 3)! They requested that they be converted to tabular firm. Only the clustered bar charts on page 358 of the published article (see Figure 4) survived this editorial cull and even this took quite a lot of persuasion! This was a disappointment to me as I am a firm believer that graphical representations of data are far better than conventional tables. 
(O2018 SAGE Publications, Ltd.. All Rights Reserved.

Figure 3. Nationality of players.

Nationality of Players in England, 1930 - 2010

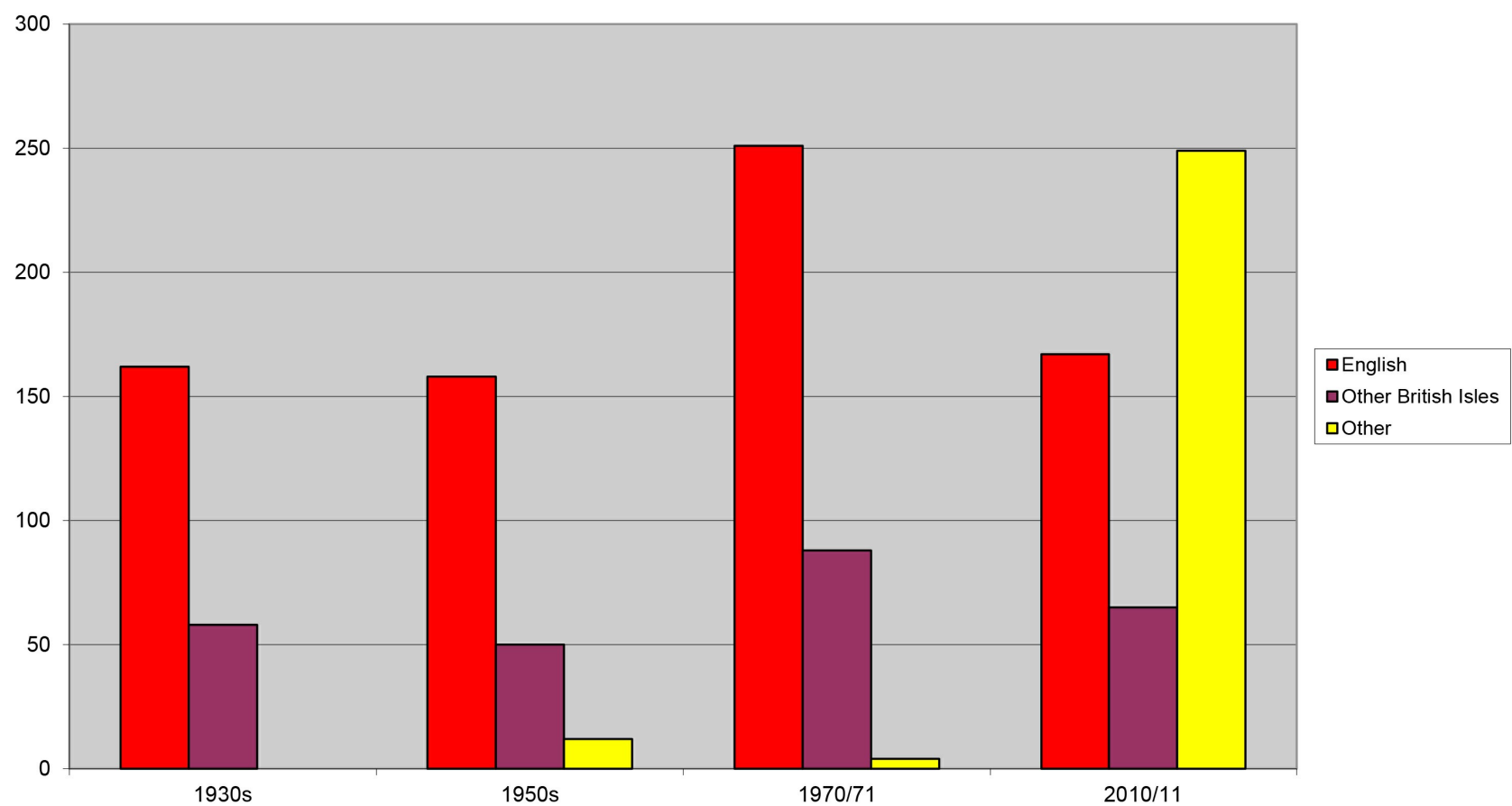

Nationality of Players in English Top Tier, 1930-2010

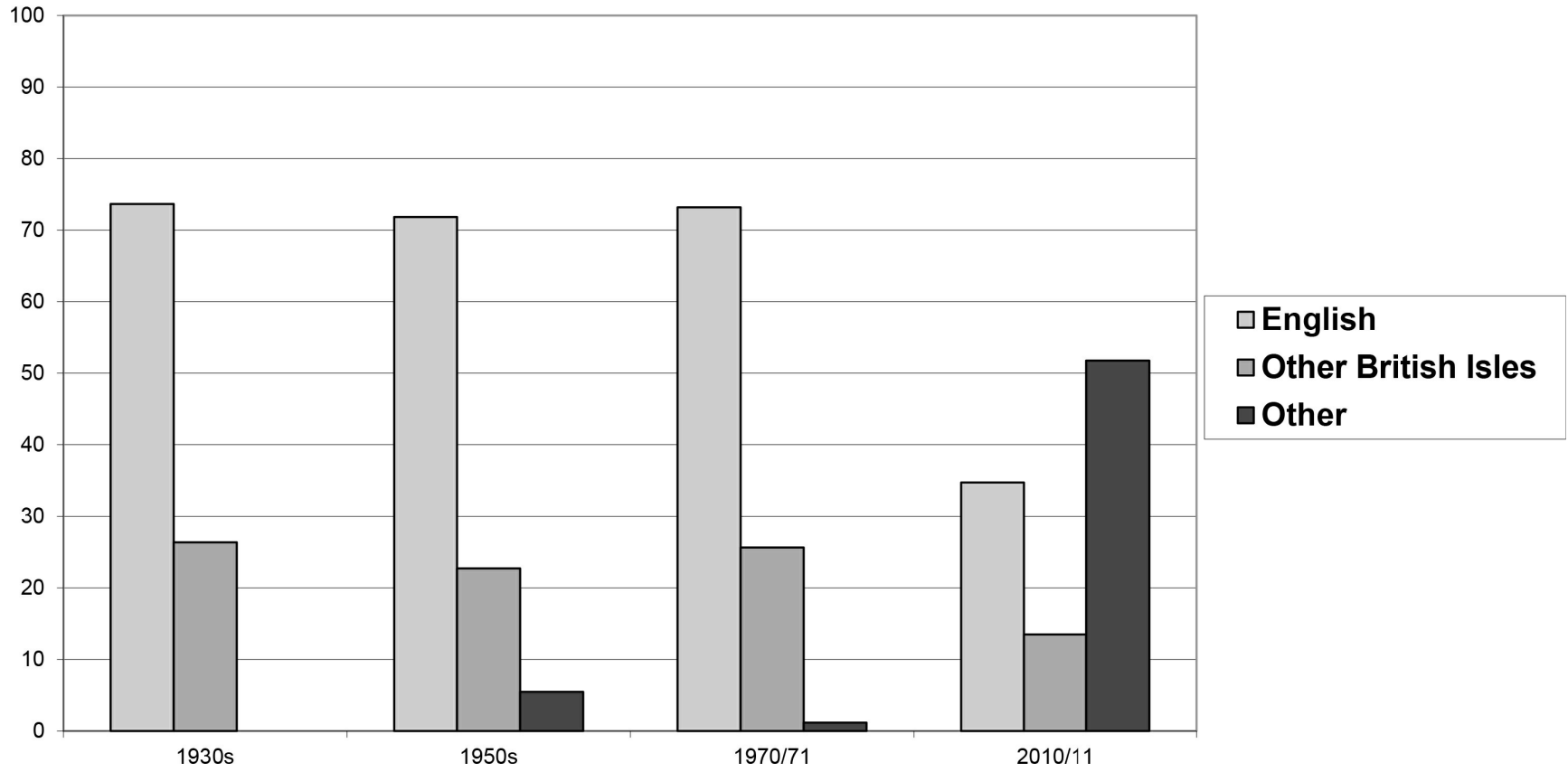


Figure 4. National origins.

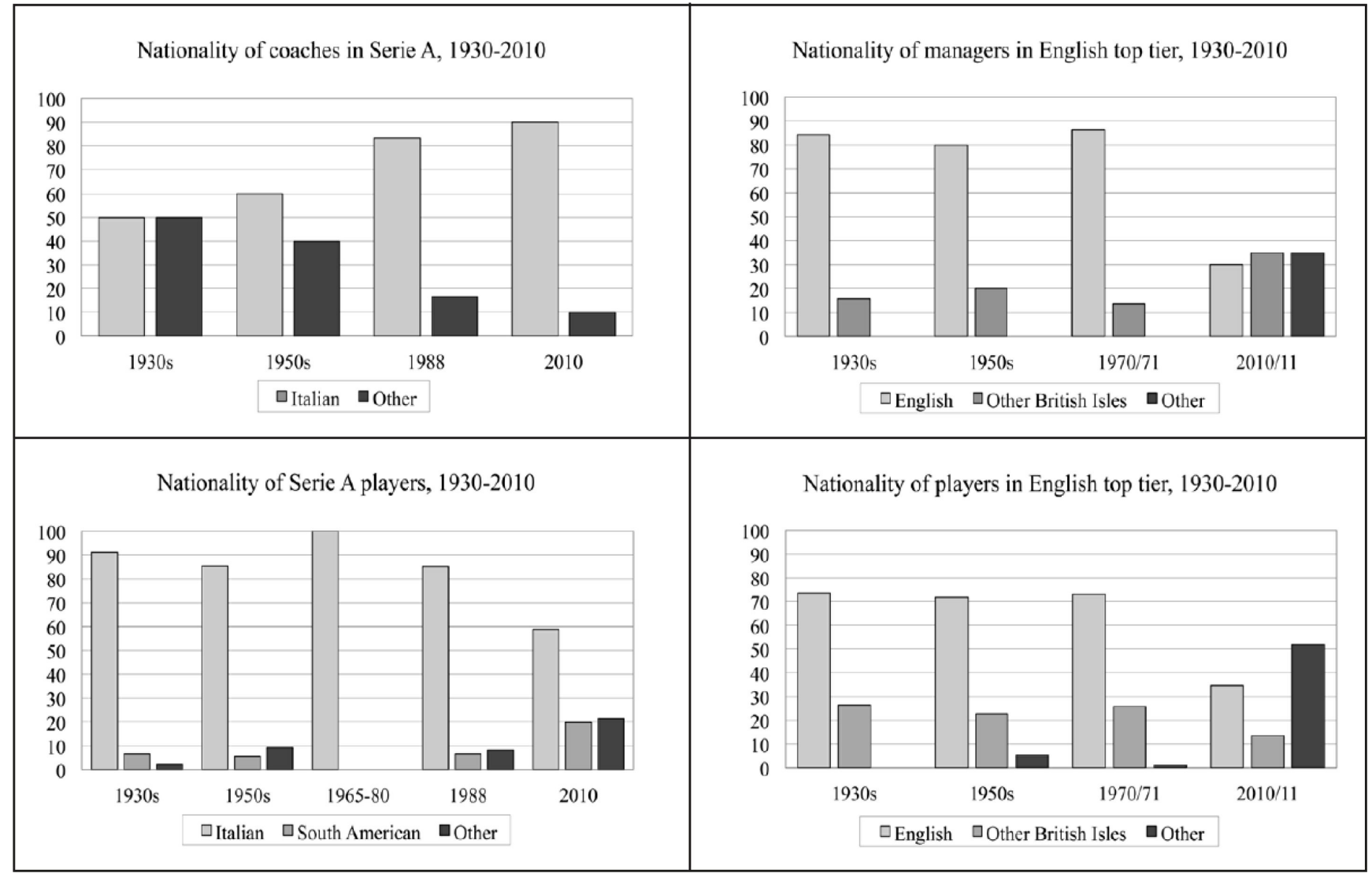

Nonetheless, I made the changes and the paper was finally accepted for publication later in 2013. My advice to other researchers is to be as adventurous as possible in the presentation of quantitative data. I think the accelerating use of the Internet to publish articles electronically will make this obstacle redundant very soon, but it is certainly something to be aware of.

\section{Conclusions}

The creative process whereby the article "Football, Nationalism and Globalization: A Comparison of English and Italian Football Between 1930 and 2010" was generated was complex. The overall comparison emerged through a series of iterations. The compilation of the data proved complicated but was based upon my desire to gather information that could be compared systematically across time between England and Italy. The interpretation of the results was framed by three sets of conceptual frameworks and informed by extensive research into patterns of international migration, the nature of labor market regulations as well as the wider sociology of football.

\section{Exercises and Discussion Questions}


1.Discuss the author's choice of research methods in the research. Which factors contributed to this choice? What role did each method play, individually and combined, in the analysis and interpretation portion of the data?

2.If you had to choose between graphical and tabular forms to represent quantitative information, which would you choose? Why? How does each method support the wider interpretative context?

3.Explain the various stages of research culminating in publication. Which stage seems the most complicated to you? Why? How would you suggest approaching that stage to mitigate the complications?

\section{Further Reading}

Abbott, M. (2016). Using statistics in the social and health sciences with SPSS and Excel. Oxford, UK: Wiley-Blackwell.

Byrne, D., \& Ragin, C. (2009). The SAGE handbook of case-based methods. Los Angeles, CA: SAGE.

Etheridge, D. (2010). Excel data analysis. Chichester, UK: John Wiley.

Yin, R. (2014). Case study research: Design and methods (5th ed.). Los Angeles, CA: SAGE.

\section{Web Resources}

Football, Nationalism and Globalization: A Comparison of England \& Italy: https://vls.uclan.ac.uk/Play/5305

\section{References}

Bickman, L., \& Rog, D. (2009). The SAGE handbook of applied social methods. London, England: SAGE.

Black, T. (1999). Doing quantitative research in the social sciences: An integrated approach to research design, measurement and statistics. London, England: SAGE.

Braudel, F. (1979). Civilisation materielle, économie et capitalisme, 15e-18e siècle [Civilisation and capitalism. 15th-18th centuries]. Paris, France: Colin.

Burke, P. (Ed.). (1972). Economy and society in early modern Europe: Essays from "Annales". London, England: Routledge.

Calcio Italia. (2010, September). 2010-11 season preview. Issue 181, pp. 38-83.

Camkin, J. (1971). Rothmans football yearbook 1971-72. London, England: Queen Anne Press. 
Etzioni, A., \& Dubow, F. (1970). Comparative perspectives: Theories and methods. Boston, MA: Little Brown.

Giulianotti, R. (1999). Football: A sociology of the global game. Cambridge, UK: Cambridge University Press.

Giulianotti, R., \& Robertson, R. (2004). The globalization of football: A study in the glocalization of "serious life." British Journal of Sociology, 55, 545-568.

Giulianotti, R., \& Robertson, R. (2009). Globalization and football. London, England: SAGE.

Hammond, M. (2011). The European football yearbook: 2011-12. London, England: Carlton Books.

Harkness, J.van de Vijver, F., \& Mohler, P. (2003). Cross-cultural survey methods. New York, NY: John Wiley \& Sons.

Hoffmeyer-Zlotnik, J., \& Wolf, C. (Eds.). (2003). Advances in cross-national comparison. New York, NY: Kluwer Academic Press.

James, G. (2016). Historical frameworks and sporting research. International Journal of the History of Sport, 33, 1169-1187.

Le Roy Ladurie, E. (1978). Montaillou: Cathars and Catholics in a French village. Harmondsworth, UK: Penguin.

Maguire, J. (1999). Global sport: Identities, societies, civilizations. Oxford, UK: Polity Press.

Morgan, G. (2007). Images of organization. London, England: SAGE.

Penn, R. (1990). Class, power and technology: Skilled workers in Britain and America. Cambridge, UK: Polity Press.

Penn, R. (2000). Il calcio in notturna e la città: Verso una economia della note [The changing times of kick-offs: towards a political economy of the night]. In E. Minardi (Ed.), Economia e Sociologia della Notte (pp. 75-82). Faenza, Italy: Homeless Books.

Penn, R. (2002). Football and local economic development (Soccer Review). Leicester, UK: University of Leicester, 2002. Available from www.le.ac.uk/crss/

Penn, R. (2004). Sport e sviluppo locale: L'esperienza del calcio inglese [Sport and Local development]. In U. Lago, A. Baroncelli, \& S. Szymanski (Eds.), II business de calico: Successi sportive e rovesci finanziari [The business of football: Sporting success and financial downsides] (pp. 131-147). Milano, Italy: Egea. 
Penn, R. (2005). Football spectators in English and Italian stadia (Soccer Review) (Vol. 4).Retrieved from http://www.supporters-direct.org/englandwales/library.htm

Penn, R. (2006a). "Le Cattedrali dello sport: Gli stadi di calcio nell" Inghilterra contemporanea [Sport and local development: The experience of English football]. In N. Bortoletto \& B. Mazza (Eds.), Tempi e Spazi dello Sport: Italia—Inghilterra Modelli a Confronto. Teramo, Italy: II Piccolo Libro.

Penn, R. (2006b). Social change and economic life in Britain bologna. Faenza, Italy: Homeless Books.

Penn, R. (2008). The English football stadium as a site of post-modern consumption: Text and image Sociologia del Lavoro, 108, 141-147.

Penn, R. (2009). Sport and health: The return of the local. In D. Jutting, B. Schulze, \& U. Müller (Eds.), Local sport in Europe (pp. 283-289). Berlin, Germany: Waxmann.

Penn, R. (2013). "Football, nationalism and globalization: A comparison of English and Italian football between 1930 and 2010." European Journal for Sport and Society, 10, 345-364.

Penn, R. (2016). Football talk: Sociological reflections on the dialectics of language and football. European Journal for Sport \& Society, 13, 154-166.

Penn, R., \& Berridge, D. (2016). Football and the military in contemporary Britain: An exploration of invisible nationalism. Armed Forces \& Society, 1-23. Advance online publication. doi:http://dx.doi.org/10.1177/0095327X16682784

Penn, R., \& Lambert, P. (2009). Children of international migrants in Europe: Comparative perspectives. Basingstoke, UK: Palgrave Macmillan.

Pozzo, V. (1960). Campioni del mondo. Quarant' anni di storia del Calcio Italiano [World champions: Forty years of Italian football]. Roma, Italy: Centro Editoriale Nazionale.

Presti, S. (1988). Annuario del calcio mondiale, 1988/89 [World football annual, 1988/89]. Torino, Italy: S.E.T.

Sappino, M. (2000). Dizionario del calcio Italiano [Dictionary of Italian Football]. Milano, Italy: Baldini \& Castoldi.

Whitley, R. (2000). Divergent capitalisms: The social structuring and change of business systems. Oxford, UK: Oxford University Press.

Whitley, R. (2007). Business systems and organizational capabilities: The institutional structuring of competitive competencies. Oxford, UK: Oxford University Press. 
